\title{
NEW DATA ON POTENTIAL DIAMOND PRESENCE IN WESTERN RUSSIA
}

\author{
Mikhailov, M.V. ${ }^{1}$, Kuznetsova, M.Yu. ${ }^{1}$, Kuzmina, T.S. ' , Polyakov A.A. ', Lukyanova, L.I. ${ }^{1}$
}

1. VSEGEI, Sredniy pr.74, Saint-Petersburg 199106, Russia

Western East European Platform is presently outlined as a major diamondiferus subprovince with predicted repeated shows of kimberlite magmatism.

The subprovince geographically comprises Leningrad, Pskov, Novgorod oblasts of Russia, as well as Latvia and, possibly, Estonia. Extensive distribution of diamond accessory minerals at different stratigraphic levels of the geological section is recorded within this territory. In some areas, contrasting dispersion haloes of diamond accessory minerals are distinguished. Typomorphism and typochemistry of minerals in haloes point to a relative proximity of potentially diamondiferous bedrock sources of minerals. There are diamond occurrences in modern alluvium of the region.

The subprovince is tectonically confined to the junction zone of the Baltic Monocline with the Moscow Syneclise, Latvian Trough and Latvian Saddle. The study area is underlain by the Cambrian, Ordovician, Devonian and Carboniferous deposits, gently dipping, south-eastwards. Differend glacial, alluvial, lacuctrine and other Cenozoic deposits occur on the eroded, surface of these formations.

In Russia, within the western Leningrad and Pskov oblasts, extensive occurence of diamond accessory minerals is recorded in the Devonian and modern alluvial deposits. On the Mga River, in its middle course, a diamond crystal is recorded in alluvial deposits. In the Devonian deposits the contents of accessory minerals range from single units to 10 units per 20 litres of heave concentrate sample. Against this background, in certain areas, contrasting dispersion haloes of minerals are distinguishead with stable contents ranging from 20-25 to 60 units. Minerals are represented by pyrope, picroilmenite, chrome-diopside and chrome- spinellid. Grain size varies between $-2+1$ and $0,25 \mathrm{~mm}$. The predominant grain size class is $-0,5+0,25 \mathrm{~mm}$ which is due to grain sizing of the enclosing Devonian sands and sandstones. Pyrope is the most widespreade mineral, accounting for $78 \%$ of the total number of grains; it is followed by picroilmenite (16\%), chrome-diopside and chrome-spinellids $(6 \%)$. Study of the chemical composition of minerals showed that kimberlites were their source. The chemical composition of pyropes points to diamond presence in bedrock sources $\left(\mathrm{Cr}_{2} \mathrm{O}_{3}-5,59-11,72\right.$ mass \%; $\mathrm{CaO}-2,61-3,53$ mass \%). Accessory minerals bear traces of hypergene dissolution in the weathering crust which makes determination of the wear degree of initial magmatogenic surface difficult. Nevertheless, for certain grains the wear degree of initial surface can be established : the prevailing class of wear is class III; however, there are also grains of the II class. It should be particularly emphasized that grains $-2+1 \mathrm{~mm}$ in size occur among picroilmenites. Minerlogical composition of the revealed dispersion haloes of accessory minerals, presence of large picroilmenite grains, presence of chrome-diopside point to kimberlite magmatism shows in the region. The chemical composition of pyropes enables to predict diamond presence in bedrock sources. Geolgical age of the predicted diamond deposits is the end of the Middle begining of the Late Devonian, since accessory minerals concentrate in basal deposits of the Late Devonian.

In the study area there are reliable data on shows of a younger kimberlite magmatism of Late Devonian-Early Carboniferous age. In the western Novgorod Oblasts, pyropes and picroilmenites are recorded in basal horizons of Earli Carboniferous. In the same area, in a relative proximity, the 
alluvial deposits contain the entire range of kimberlite minerals, including diamonds, pyropes, picroilmenites, chrome-diopsides, chrome-spinellids. Here 5 crystals of small diamonds were found. The most significant result of heavy concentrate-mineralogical sampling is the discovery of rather large (grain size class of $-4+2 \mathrm{~mm}$ and $-1+0,5 \mathrm{~mm}$ ) non-worn pyrope grains in modern alluvium. Four grains are represented by oxygonal fragments of initial magmatogenic finely-shagreen surface, one grain is absolutely complete, oval, its entire surface is covered by magmatogenic shagreen. There are no indications of mechanical wear and hypergene alterations on the grain surface. Besides, kelyphitic rim relics are recorded on the magmatogenic surface of one of the grains. The composition of kelyphitic rim is determined using microprobe analyser. The chemical composition of pyropes ( $\mathrm{Cr}_{2} \mathrm{O}_{3}-6,51-12,08$ mass\% $\% \mathrm{CaO}-5,03-7,26$ mass\% ) points to belonging to duniteharzburgite and high-chrome lherzolite paragenetic associations, characteristic of diamondoferous kimberlites.

The occurrence of non-worn pyrope, chrome-diopside and picroilmenite in alluvium points to the immediate proximity (the first kilometres) of the initial bedrock sources. The chemical composition of pyropes and diamond occurrences are indicative of diamond presence in kimberlites (Mikhailov, Semenova and Sukholinsky-Mestechkin, 1996).

In terms of evaluating potential diamond presence in the region it is essential that injections of alkaline-ultrabasic magmatic material were discovered in the Upper Devonian deposits. Comprehensive petrographic, $\mathrm{x}$-ray and $\mathrm{x}$-ray spectrographic studies of borehole core enabled to reveal tuffisite ( intrusive tuff) bodies. Intrusion of the latter proceedeed under a near-surface environment and resulted in generation of peculiar breccias cemented by magmatic material in the red Devonian marls and clayey-carbonate roks. Time of intrusion of tuffisites is the Late DevonianEarly Carboniferous.

In Latvia, diamond accessory minerals were recorded by the Latvian geologist in modern alluvium and Upper Devonian deposits within Kurzeme Peninsula (Sorokin, Krivopalov and all, 1992). Pyropes, olivines, high-chrome chrome-spinellids and single picroilmenite grains are discovered in alluvium. Mineral concentration reaches tens of units in a 20-litre sample. In the Famenian (Upper Devonian), pyropes occur in high concentrations along with the presence of slightly rounded grains.

Therefore, shows of basitic magmatism in the region, diamond occurrences, presence of nonworn accessory minerals, high concentration of minerals, their chemical composition point to potentials of the western East European Platform in terms of discovering diamond deposits.

\section{References}

1. Mikhailov, M.V., Semenova, M.P., and Sukholinsky-Mestechkin, S.L., 1996, Potential of diamond presency in the Msta-Demyan field ( Western Russian Platform, Novgorod oblast): Abs. volume IV Int.Forum"Mineral Resources of CIS States",St.Petersburg, p.49-50

2. Sorokin, V.S., Krivopalov, Y.I., and all, 1992, Eventing stratigrafy and potential diamond presency in Western Latvia: Coll. stories ,Paleontology and stratigraphy in Phanerozoic of the Latvia and Baltic Sea, Riga, p.77-80 